\title{
At the Sea's Edge: Elders and Children in the Littorals of Barbados and the Bahamas
}

\author{
Brent W. Stoffle • Richard W. Stoffle
}

Published online: 25 January 2007

(C) Springer Science + Business Media, LLC 2007

\begin{abstract}
Littorals in the in the Exuma Cays, Bahamas and the Bath Plantation, Barbados are comparative in many ways. These edges of the sea have provided critical services to local people during the time of slavery and since. More than food and medicine, the littoral is the nightly sea bath, where children are instructed, and the last ecosystem effectively used by the elderly. Independence and selfrespect derive from use and protection of these littoral by individuals and communities. Local patterns of conservation and use are argued to be essential in the ecological structure and functions of the littoral. Development projects and marine protected areas alike are seen as potentially breaking local ties with the littoral causing trophic skew and damaging local society. If development occurs, mitigation solutions potentially derive from legally recognizing local people as partners in the co-management of their traditional littoral.
\end{abstract}

Key words Marine protected areas · social impact assessment traditional coastal communities $\cdot$ co-adaptation . environmental conservation

The Sea at its best is a place where I can walk in the water up to my knees and look down and see conch, fish and other foods for life. It should all be there for you. Lester Flowers, Professor of Biology, College of the Bahamas

\footnotetext{
R. W. Stoffle $(\square)$

The University of Arizona,

Tucson, AZ, USA

e-mail: rstoffle@email.arizona.edu

B. W. Stoffle

Southeast Fisheries Science Center, Miami Facility,

NOAA, NMFS,

Miami, FL, USA

e-mail: brent.stoffle@noaa.gov
}

\section{Introduction}

Edges are special places for human ecology (McCay, 2000; Turner et al., 2003) because critical natural and human life cycle events occur there. In the Caribbean the edge of the sea is especially important for fish nurseries, mangrove wetland nutrient exchanges, and people. This is a place where fresh water touches salt water, birds nest, and amphibians thrive. Here too people begin and end their lives.

Unlike other important areas in the terrestrial and marine environment, the human dimensions of the Caribbean littoral tends to be underrepresented or misunderstood in ecological studies and in the social impact assessment portions of environmental planning studies. Thus this paper re/focuses and re/centers such studies by ethnographically and diachronically describing this social-ecological place in Barbados and the Bahamas. Examples from two former slave communities illustrate a pattern, occurring over hundreds of years, of environmental learning and adaptation which involves the sustainable use of specific species in the littoral. These patterns of adaptation explain why the littoral has become culturally central to the people of these former slave communities and why they have established a sense of customary ownership and responsibility for protecting the littoral, treating it as "family land" (Besson and Momsen, 1987; Barrow, 1992).

Having been ignored by plantation agriculture, today the littoral is being stressed by industrial development projects, tourism facilities, and Marine Protected Areas (MPAs). Ground disturbance is an obvious aspect of building along the coast, but even new MPAs can shift the human-nature balance by removing local peoples. No-take MPAs are designed to restore and protect the marine environment and establish new balances in human-nature relationships, and 
they do so by restricting consumptive access of all people to certain areas (NRC, 2001). One attractive feature of notake MPAs is that they are easy to monitor and police because no one, whether local or outsider, is permitted to fish or collect marine resources. While both conservation and development projects can be economically beneficial, resulting changes in access to and use of the littoral can disconnect the coastal people from "their" sea. This human-nature disconnect is non-trivial for it involves both places essential in the lives of coastal people and changes in the biodiversity of the littoral. Such impacts should be a part of a scientific social impact assessment of MPAs and development projects (Christie et al., 2003).

\section{Methods and Assumptions}

The analysis is generally informed by more than 30 years of research conducted by the authors among the residents of coastal communities in the Caribbean. These research projects occurred along coasts in Barbados, the Bahamas, Antigua, St. Lucia, and the Dominican Republic (Rubino and Stoffle, 1990; Stoffle et al., 1994a,b; Stoffle, 1986, 2001a). This paper is primarily based on more than a thousand quantitative and qualitative interviews collected in two Caribbean areas - the island of Barbados and the Exuma Cays in the Bahamas.

The Bahamian interviews occurred as part of a five-year study of how attachments to the sea can influence people's willingness to support or reject MPAs located near their home community. This study was stimulated by the Bahamian government's plan to set aside $20 \%$ of their ocean in no-take MPAs (Lutz et al., 2002). During six field sessions students and faculty from the University of Arizona and the College of the Bahamas conducted 546 interviews over eight field sessions with people from six settlements in the Exuma islands and cays; of these interviews, 65 were with the people of Little Farmers Cay. The interviews results were consistent among communities and with previous MPA research in the Exumas (Mascia, 2000). A sea attachment survey form guided data collection. Follow up formal interviews used specialized instruments focused on the history of resource uses and GPS-referenced sea use mapping.

The Barbados interviews were conducted during a 3-year study of traditional microeconomic systems of exchange, especially those focused on rotating savings and credit associations (variously known in the Caribbean as meeting turn, sou sou, asu, box hand, and partner) (Gmelch and Gmelch, 1997). During five field sessions a single researcher (Stoffle, 2001a) conducted 500 interviews in Barbados; of these interviews 120 were with the people of the Bath Plantation area. Interviews collected data on microeconomic systems which are a creole (or informal) economic system (Browne, 2004). Responses regarding direct production from the sea provided data on patterns of littoral use.

This analysis assumes that broader patterns of Caribbean life, especially ones occurring over the life cycles of individuals and traditional patterns established over many generations can be understood through systematic interviews as well as through a few typical stories from a single settlement. The thousand plus interviews established the cultural centrality of the littoral in the lives of people in coastal Barbados and the Exuma islands and cays. This essay situates these findings through the diachronic story of two settlements.

\section{The Littoral in the Carribbean}

The term littoral is used in many different ways. Some scholars restrict it to the wet portion of the coast between high and low tides (Mokyevsky, 1960), whereas others view it as a general term of reference for socially and biologically integrated portions of the sea coasts. These ideas are combined to operationally define littoral to mean that portion of the sea immediately adjacent to the land but no deeper than the waist of an adult at low tide. It includes places on land that are socially and biologically connected with the sea. The littoral extends onto the land through food webs that critically depend on both salt and fresh water habitats. Thus, it extends up estuaries into mangrove wetlands, and as far as amphibious animals like crabs travel inland. Minimally the littoral involves the following kinds of places: shallow coral reefs, sea grass beds, exposed beach rock, foreshore, backshore, sand dunes, sea cliffs, mud flats, estuaries, mangrove swamps, brackish ponds (anachialine), fresh water deltas, springs, and streams.

Socially and culturally the littoral extends into the contemporary activities, history, and culture of traditional communities which are adapted to where they have lived for generations. So the littoral also exists where it participates in the lives of coastal people. There are many resources in the littoral that are organized as a set of biotopes, which are defined as an area that is uniform in environmental conditions and in its distribution of animal and plant life. Biotopes are bound together through complex food webs and trophic levels which are greatly influenced by the ratios of fresh to salt water and nutrient exchanges. The system is subjected to perturbations from violent storms, changes in rainfall, and human disturbance.

While some have argued that humans have largely had adverse impacts on the littoral (Ellison and Farnsworth, 1996, Rogers and Beets, 2001; Roberts, 1995), it is argued here that traditional coastal communities become adapted to 
their environments and can positively influence biodiversity (Anderson, 2005; Atran et al., 2002; Davidson-Hunt and Berkes, 2003; Folke et al., 1998; Lamont et al., 2003; Lewis and Ferguson, 1999; Nabham, 1995, Sillitoe, 2001). Here, following evidence presented by Connell (1978:1305) we are looking for disturbances ranging from catching fish, collecting plants, and clearing forests, to burning. We maintain that long-term patterns of ecosystem use by humans can constitute an intermediate disturbance which is assumed to increase biodiversity as would the activities of any other keystone species. Thus, we maintain that no part of the coastal ecosystem, including the human component, can be modified without threatening to shift the relationships of other parts of the system - an event that can be defined as a trophic skew (Duffy, 2003).

\section{The Exumas, Bahamas}

There are many edges in the Exumas, which are a northsouth trending chain of various size calcariferous cays and small islands perched at the rim of a large shallow bank that is bounded in the east by a deep ocean sound. Much of the bank is a few meters in depth while the Exuma Sound is immediately $30 \mathrm{~m}$ deep at the cliff that defines its boundary with the cays. Extending more than $30 \mathrm{mi}$ to the east until delineated by the Eleutherian Cays, Exuma Sound is up to 1,000 $\mathrm{m}$ deep. Situated between two very different bodies of water, the Exuma Cays experience fast shifts in tidal characteristics, rapid reversing currents, and varying water temperatures. These physical forces combine to influence local ecological conditions along the bottom substrate and coastal margins of all islands and cays. Coastal location critically influences the productivity of the sea itself as it washes across coral reefs and mixes with fresh waters from the land. Location defines areas that are protected from storms, surges, and persistent winds. These patterns of sea and air movements have existed for millennia so the very shape of the islands and cays have been subsequently eroded. Rain is the only source of fresh water and it absorbs directly into the land to be distributed on the surface by topographic features. In turn, plants and animals thrive where they find the appropriate combination of water, soil, and shelter provided by these shaping forces.

\section{Exumas Historically}

The Amerindians who occupied these cays of the central Bahamas for thousands of years were the first human keystone species in the ecosystem. They fished, cut mangroves, farmed, hunted birds and mammals thus meeting the use of this concept by Menge et al. (1994). Some scholars see their arrival as being associated with the extinction of hundreds of species. But the human arrival dates used by these studies are for the middle Holocene (4-5K BP) which was a time of extreme climatic and ocean shifts (Robert, 1989). Recent archaeology places Amerindians in Florida nearer the beginning of the Holocence (10,000 plus years ago) when no massive extinctions occurred (Milanich, 1994: 46). Whether they were the destroyers of the environment or simply a keystone species that modified it for thousands of years, humans then and now are an ecological force which must be understood (Wing and Scudder, 1983).

These first human inhabitants of the Bahamas were either killed by European diseases or removed by the Spanish more than 100 years before the English arrived in the 1600s (Craton and Saunders, 1992: 56-57). Between Spanish and English occupations, these marine ecosystems had a century or more to adapt without a human keystone species. Thus the Bahamas functionally became a single no-take MPA. Considerable changes in the system are assumed to have occurred given what we know about similar environmental changes elsewhere in the Caribbean. ${ }^{1}$ These ecosystem changes did not mark the return to a naturally balanced or stable system (Pimm, 1991), but were instead biological responses to a major disturbance in the ecosystem, that is, the removal of the humans.

For roughly 150 years after the removal of Indian communities from the Bahamas, few people inhabited the archipelago. As early as 1648 , a few Bermudian settlers arrived in the area, settling on Eleuthera and using the Exumas for salt collection and for spermaceti whale harvesting (Craton and Saunders, 1992: 79). In general, however, the ancestors of the people who currently live in settlements in the Exuma Cays arrived at the end of the American Revolution in 1785, when English colonists still loyal to the King and having little faith in the new revolutionary state, requested help from the Crown to relocate to other English colonies. About 1,600 white slave owners and 6,000 African slaves moved to the Bahamas to occupy more than 100,000 acres of "new land" (Craton, 1987: 92). Much of the best land had been occupied, so these loyalists tended to be relocated to the most isolated and unoccupied portions of the Bahamas, like the Exumas.

The slaves and small plantation owners began the process of clearing the land and building a commercially viable corporation. However, within 10 years most plantations had failed for both ecological and economic reasons. Ecologically there is very little rain and soil in the Exumas. After the mixed hardwood forests were cleared and sold for

\footnotetext{
${ }^{1}$ Along the north coast of the Dominican Republic, for example, after the removal of Indian communities the forests covered former Indian fields and villages, mangrove wetlands replaced salt production ponds, and three foot long lobsters became common in the littoral (Stoffle et al., 1993; Stoffle, 2001b).
} 
whatever could be gained, cotton was planted as the major commercial crop. Not only is this crop very hard on the land, but strong storms soon stripped the soil from the fields. Without soil the land was worthless as commercial property and the slaves were increasingly left to support themselves with small subsistence garden plots, wild plant collecting, hunting, and shallow water fishing (Sheridan 1976: 625-627). Economically the new plantations were always marginal: because of English restrictions on trade with the American colonies they produced for very distant and poorly connected markets; and because they involved Crown lands that were free of initial charges and quit rents for only 10 years (Craton, 1987: 92). The Crown maintained that the loyalists had conditional tenures that depended on the development of the land. After a decade most loyalist plantations failed to meet these criteria, thus the land legally reverted back to the Crown. Due to regulations against moving slaves from colony to colony and because of the economic failure of the plantation system in general, most lands and physical improvements were simply abandoned by 1800 .

Each failed plantation was now exclusively occupied by the former slaves who came to own the land through usufruct and as a common community. Such customary landholding systems are called generational land or family land throughout the Caribbean (Besson, 1987). The exslaves, as individuals and as a corporate community, took the name of their plantation. This remains a recognized mark of ownership of plantation lands for individuals and settlements.
After the failure of the plantations, no food was imported to support the former slaves, so attention must have turned immediately to the most accessible ecozones, like the forests and the littoral. Since the former had largely been cut down, they turned to the littoral, where, without the need for complex technology, they could find animal protein, materials for building homes, and medicinal plants. We argue that were it not for the resources of the littoral most former slaves would have died soon after abandonment by the loyalist planters.

\section{Little Farmer's Cay Today}

The littoral was a lifesaver in the past, and it remains a safety zone in the minds of Exuma people today. Many of the use patterns that developed after slavery have persisted simply because they are the foundation for a high quality way of life. As a region of security the littoral has become a part of how people view themselves and it is where they teach the lessons of life to new generations. This region is viewed as belonging (due to usufruct) to the settlement. The littoral is like generational land, although it is not recognized as being traditionally owned by the Bahamian post-colonial legal system.

The establishment of Farmer Cay settlement, located in the northern Exumas (Fig. 1), illustrates how the littoral has become central in people's lives. According to documents and consistent oral accounts, at the end of slavery a few

Fig. 1 Looking east towards Exuma Sound from Exuma

Bank at a cut between cays near Little Farmer's Cay.

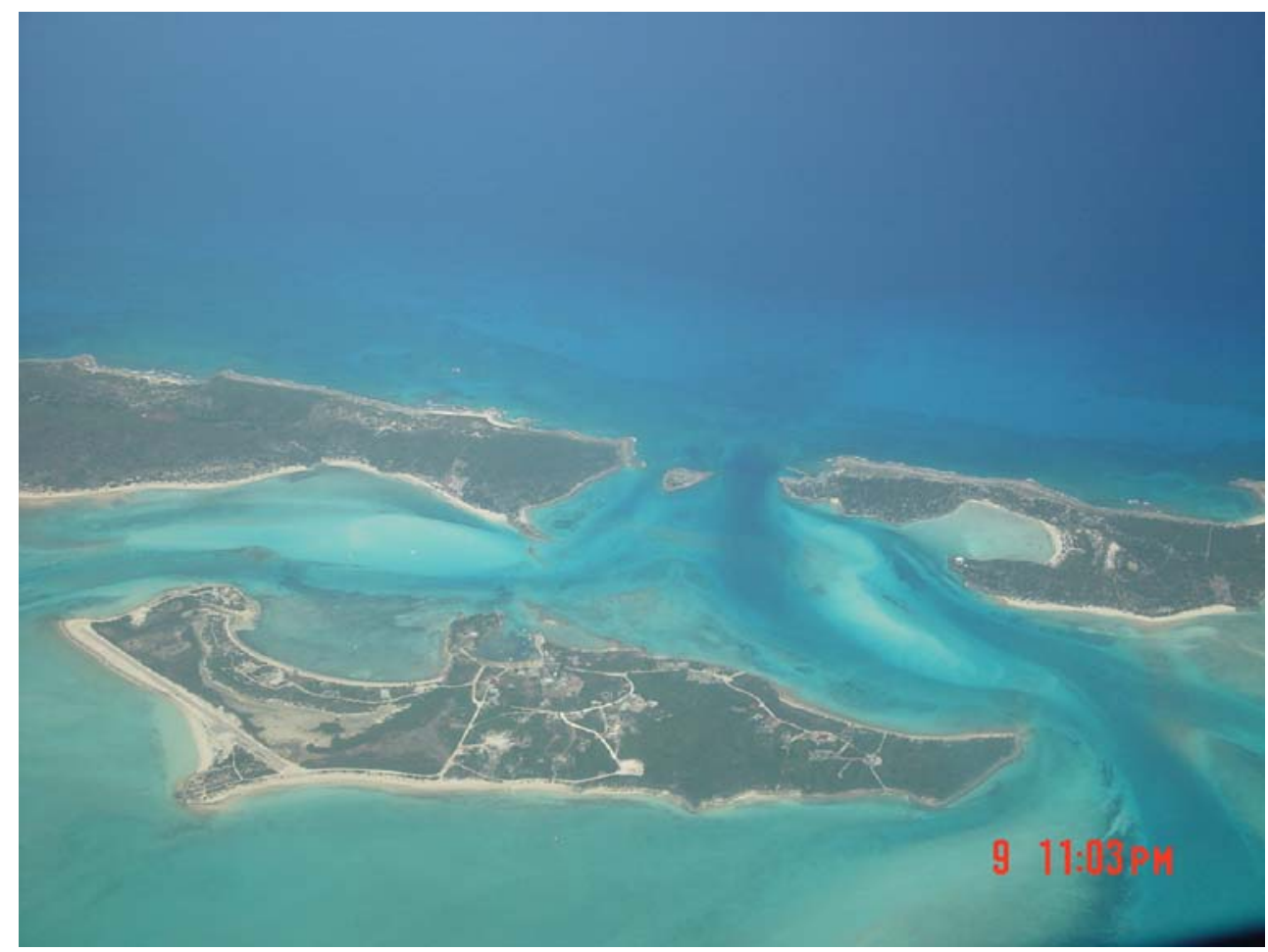


families left Exuma Island in 1835 to settle on six small unoccupied cays to the north (Bain, 1995). Unlike the Exuma Island settlements, which have all the necessities of life in one location, the six small cays and the intervening sea had to be combined to make life possible for these families. When they first arrived, they set up the primary settlement on Big Farmer Cay (BFC), but when it proved vulnerable to storms, they moved nearby to Little Farmer Cay (LFC). This cay is protected from storms, but is totally dry. So every day or two the young women from each family would scull a small boat over to the spring on BFC in order to fill a barrel of water for domestic use. Each week these women would scull all their dirty clothes across to a spring on BFC where they would spend the day doing the washing. This spring became the center of social life for most adult women.

Given a lack of fresh surface water and thus a constant state of water shortage, local people positioned their homes near the sea so that they could take a daily sea bath. Each family had its special place where the sea was quiet, the sand was smooth, and coastal trees afforded a modicum of privacy. Often during a sea bath a quantity of sea water was consumed for health so the water had to be free of pollution.

Young women and men would regularly scull the elders eight miles to a large cay in the south where there were agricultural fields that needed regular attention, including hand irrigation with fresh water. At the end of the day they would scull the elders back to LFC against the prevailing winds. These journeys entailed traversing six major gaps between cays where strong tides flowed in and out four times a day potentially threatening the small boats.

Children did not accompany their parents on long sculling trips when their parents were fully occupied with the dangers of tides and winds during the trip and then with agricultural work. As a result, LFC with its sheltered beaches became the place where the children spent most of their time. With their grandparents, they walked along the sandy beaches to pick the top of a palm which is woven into many useful items, and to collect sea moss garden mulch to supplement the thin layer of soil on top of hard fossil coral.

Both men and women have always fished. This is rare in the Caribbean where fishing is normally done by men; however, it was a positive adaptation to a situation where the men of the settlement often left for long periods to exchange products in Nassau. During these absences the women would both garden and fish to support the settlement. A fisher or group of fishers would provide fish for each family in the settlement, dividing and personally delivering the day's catch to each household, where they would receive a shot of rum. This pattern of asymmetrical reciprocity illustrates how the community became the social unit of adaptation.
Conch would be taken from its shell at the water's edge where the shells were stacked in high piles, often on top of or near conch piles made by Amerindian people. Traditionally, some buildings were made of solid cement derived from cooked conch shells (cf. Farnsworth, 2001), roofed with solid beams from the mangrove that were resistant to termites and further sealed with a woven palm top.

The people of LFC have many kinds of relationships with the sea beyond subsistence. The study team repeatedly observed a large ray swimming slowly in the main harbor. Its behavior reflected an apparent lack of fear and we speculated that it might be a local "pet." When asked about the ray in the harbor, one person said that he would never consider eating the ray because it ate their garbage. A second person, while cleaning fish standing up to his waist, in the water fed scraps to both cats on shore and the nearby ray. When asked if he was actually leaving food for the ray, he said yes, that the ray would eat it and also nurse sharks if they came around. While it was not exactly a domestic pet relationship, the ray had coadapted its feeding patterns to include cruising the harbor looking for the unwanted portions of fish that local people have become accustomed to leaving for it and perhaps nurse sharks.

These adaptive patterns of settlement life remained largely unchanged until about the mid-1950s, when foreigners began to purchase, with the permission of the national colonial government, whole cays for personal use in fee simple title. These purchases violated the concept of generational land and marked the beginning of a battle over the legality of customary ownership by settlements. The process has accelerated so that now large portions of the cays initially used by the people of LFC have been lost to tourists and tourist corporations. Traditional sea use areas have been encroached on by outside commercial fishers who use large boats with big nets to catch all the fish during spawning aggregations, and crews of divers strip fish drops of all the breeding stock. Yachters now anchor in the shallows and fish off board and dive for the readily accessible conch in the shallows. Each of these encroachments has reduced the ability of the settlement to remain independent and has forced increasing numbers of youth into wage labor jobs in Nassau and overseas.

Tourists have caused two types of human-ecological impacts in the littoral. A dramatic change occurs when tourists catch conch. Along a portion of sand beach in LFC are recent piles of undersized conch adjacent to dozens of piles of large adult conch, many of which date back to Amerindian times. According to one of the oldest women, the juvenile conch piles are due to her collecting in the shallow water, because there are no longer adult conch in the littoral. She attributed the decline in adult conchs to the yachters who anchor nearby and legally collect conch for 
their personal use. Since she can no longer swim, she must collect what is available near the shore, which is increasingly smaller and smaller conch, which she continues to collect even though the young men do share their catch with her, because she wants to exercise her right to use the littoral and remain independent.

According to the Convention on International Trade in Endangered Species no one can move conch shells across international boundaries. Thus yachters who catch conch in or near the littoral either throw their empty shells back into the sea or take them to shore. Local fishers, following the pattern of their Amerindian predecessors, never return a conch shell to a conch gathering area in the belief that empty conch shells interfere with live conch breeding. There is no scientific literature showing that empty shells in the sea grass beds reduce breeding effectiveness. Also the conch may be breeding in areas far from the local sea grass beds, which may function instead as a recruitment area for young conch. There is, however, one circumtance in which empty shells could reduce the number of conch and therefore appear to impact breeding. The empty shells of adult conch are used by giant hermit crabs to protect them as they roam over the entire sea grass bed. Such crabs are sufficiently large to eat juvenile conch. If adult conch shells are consistently removed from the sea grass beds, over time the number of giant hermit crabs in the patch would decrease and the number of conch in the area would increase.

Direct evidence of an association (not a proven causal relationship) between human conch deposition and the size of conch patches is provided by Stoner (1997). In the Exumas his team documented that the largest conch shell mounds dating back to Amerindian times are contemporarily associated with the largest patches of live conch. It appears that either people fished more in large conch patches or large conch patches exist because of fishing practices. Either way, the study documents that traditional local fishers have not adversely impacted the conch populations.

Today, 222 years since their arrival and a 172 years after slavery ended, the people of the Exumas confront an array of threats to the way of life they coadapted with this coastal marine environment. Now they face massive casino-and condo-based tourism facilities, the purchase of whole cays by outside corporations who rent them to tourists for $\$ 350,000$ a week, and numerous proposed no-take MPAs all of which directly encroach on and reduce their generational lands, including the littoral and the sea.

\section{The Bath Plantation Area, Barbados}

Unlike other Caribbean islands which are composed of a chain of volcanic mountain tops that are often visible one from another, such as the Lesser Antilles, or islands which are a part of an exposed coral plateau, such as the Bahamas, Barbados is alone in the Atlantic Ocean. Although once a square block of coral, prevailing NE ocean winds and waves have eroded Barbados into the shape of a pork chop with steep cliffs and sharp ocean drops on the NE coast and calm beaches and flat sand and narrow coral banks on the leeward coast (Fig. 2).

Barbados was the social edge of English plantation slavery beginning in the early 1600 s. The first unfree laborers (Williams, 1944: 7) in Barbados were Scottish and Irish prisoners of war sent by Lord Cromwell between 1650 and 1660 and sold for 1,500 lbs of sugar a head to planters (Frank, 1920: 372-373). The prisoners wore kilts, so the tropical sun badly burned their lower legs, hence the nickname "red legs" (Sheppard, 1977). This practice of exporting political prisoners continued until 1746 when Highlanders taken prisoner at the battle of Culloden Moor were exiled to Barbados as unfree laborers. By the mid1600 s sugar had replaced cotton, African people had replaced the Scottish and Irish as the major source of labor, and large sugar plantations had supplanted small farmers (Watts, 1994: 176-231). By the third quarter of the seventeenth century there were more people in Barbados than in any of the mainland English colonies, so with an enormous population density and competition from industrial agriculture many small-scale Barbadian planters and their slaves relocated to the new Carolina colony (Wood, 1974: 7-8).

Being physically isolated, there was no hinterland in Barbados to which unfree laborers could escape. Barbados was one of the most socially and environmentally restrictive places in the Caribbean, used as an entrepot (or place of forced acculturation and reshipment) for people from Africa and a maximum security prison for prisoners of war.

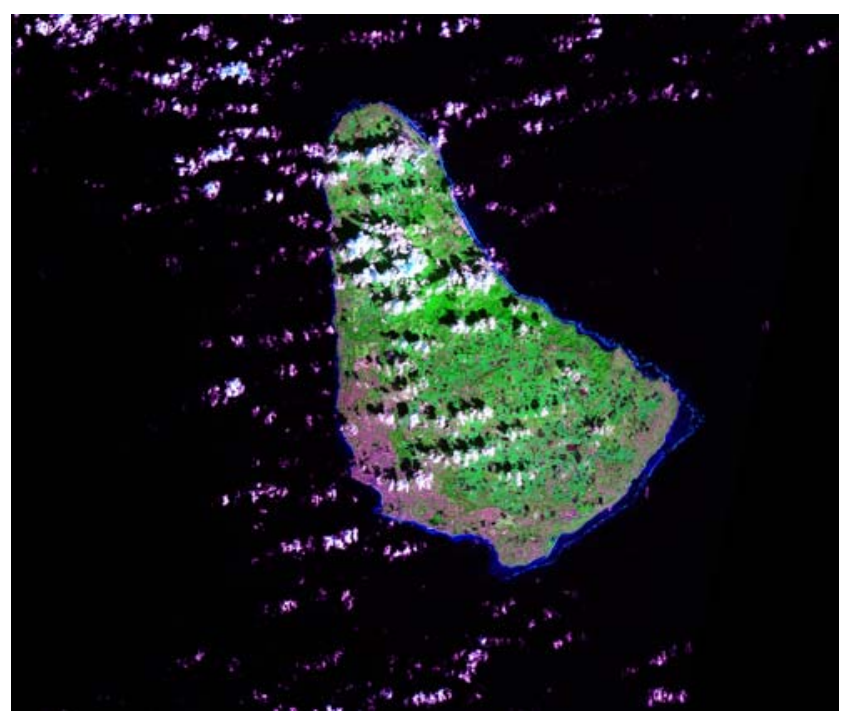

Fig. 2 Barbados showing narrow coral reef shelf dropping off into deep ocean. 
If new Africans learned the language of the plantation (which tended to be Scots-Irish) and exhibited a willingness to adapt to plantation life they were often resold to English slave plantations with extensive hinterlands, like the Carolina colony.

In contrast to the 700 islands of the Bahamas which served during this period as a massive largely unoccupied hinterland to Nassau, Barbados was stripped of its natural surface vegetation within a generation of settlement in 1627 and fully farmed. The sea was the only natural frontier, but without good boats it remained largely inaccessible. Thus, the Barbadian littoral became the only place for the ScotsIrish and slaves to collect for subsistence and trade in the capital market.

\section{The Bath Area Historically}

This second example of how local people in the Caribbean have co-adapted with the littoral is focused on the contemporary communities surrounding the former Bath Plantation (Bath Area) located on the east coast of Barbados. The Bath area is approximately an hour by car from the capital, Bridgetown, and even though Barbados is still characterized as one of the most densely populated countries in the world, it is a collection of rural communities all surrounding the former sugar cane fields of the plantations. There were two major plantations in the area, Bath itself and Codrington located about a mile away. Both contributed to the development and history of the area, but much more is known of slave conditions on the Codrington Plantation (1710-1874) because it was used to support the first college in the West Indies and has thus became the focus of many studies (Bennett, 1951; Loftfield, 2001: 219-232). This analysis uses data from Codrington to understand events on the Bath Plantation, and the littoral adaptations of both their workforces during slavery. Contemporary interviews, both survey and oral history, serve to define recent patterns of littoral use and cultural centrality. The people of Bath, both Scots-Irish and Afro-Caribbean, have accumulated a great depth of traditional ecological knowledge about the marine environment as many generations used the littoral during slavery, after emancipation, and today.

Unlike the Bahamas, slaves along the NE coast of Barbados seem not to have fished. Slaves were so expensive and died so fast on Codrington that it was not economically feasible to release them from productive labor to fish, even though fresh fish (and reduced labor requirements) were provided to newly-arrived African slaves - "unseasoned slaves"- for 3 years in an effort to reduce their extremely high death rate. Fresh fish also was desired by the plantation owners and the students and teachers of Codrington College, which was supported by slave labor. The data suggest that Codrington Plantation hired and regularly purchased fish and other sea products from the local free Scots-Irish fishers from Scotland District about ten direct miles up the coast. Consequently these people probably laid the cultural foundations for contemporary littoral use patterns.

Barbados settlement patterns have changed little since slavery because after emancipation in the early 1830 s slaves lacked access to new lands and jobs thus many continued to live on and do wage work for the plantation that had enslaved them. Purchase of land by slaves was made almost impossible by the Land Purchase laws requiring that large quantities of land be purchased at one time and for very high prices. According to Trollope (1860 [1980]: 199) "When emancipation came there was no squatting ground for the poor Barbadian. He had still to work and make sugar - work quite as hard as he had done while yet a slave. He had to do that or to starve."

The end of slavery did mean that plantation owners no longer provided former slaves with subsistence provisions, housing, clothing, and medical support. Especially important was the loss of salted fish which was often their only source of animal protein. Former slaves increasingly depended on house gardens, local small scale farming, animal husbandry, and fishing.

Almost 8,000 of the Scots-Irish plantation workers were displaced from their wage work on plantations at emancipation and became almost totally indigent. According to Sturge and Harvey (1968: Appendix E: xxvi) in 1837 most all of the pauper population in Barbados were "red shanks" who became so "due to the competition of the colored people who have driven them out of almost every field where free laborers were wont to exercise their skill and industry."

Because former slaves and the Scots-Irish both lacked boats and most types of fishing equipment, they focused on the littoral, the safest and most accessible place to harvest species for home consumption and market sale. Throughout the late 1800 s and into the twentieth century, littoral fishing was a mainstay for local communities. A photo of poor white fishermen taken around 1910 inventories their fishing gear as specialized for near shore angling and net casting (Yates, 1998: 151).

\section{The Bath Area Today}

The Bath area, like most places in Barbados, is composed of people whose ancestors once worked on the main plantation. Now with the plantation idle, the formal economy of the Bath area is based on tourism, retail of grocery products, small-scale agriculture, and small-scale construction. At the bottom of Bath Hill (east towards the coast) is Bath Beach, a beautiful area that regularly attracts foreign tourists as well as Barbadian nationals. 
It is the job of approximately 15 local people to care for and protect the beach and near shore ocean area. They are hired by the National Conservation Commission (NCC), and are responsible for the upkeep of the grounds, the protection of turtles that come to nest and lay eggs, and the safety of tourists. All are local community members who have benefited from the formalization of the beach and other portions of the littoral as a government park. In this area with few jobs, they are able to engage in wage labor and not leave the community. On a daily rotating basis, ten people are responsible for the park up-keep and maintenance of the beach area. There are five lifeguards who care for the public and two night watchmen who provide security for people and the beach houses. Two people are responsible for protecting the environment, including watching over sea turtles that come up on the beach to lay eggs.

It is almost always possible to find someone fishing in Bath waters. The fishing grounds extend seaward into deeper water, covering a productive inshore reef and offshore deepwater fisheries. The shallow inshore fishing grounds have many types of targeted species including lobster, crab, conch, whelk, seacat (octopus), reef fish, grouper, cavaelli, and night feeding pelagic fish such as barracuda and jacks. Fishers from the area use spear guns, hand lines and cast nets.

Middle-aged men and boys tend to stay on the inner shoals looking for seacat (a type of octopus), crab and the occasional reef fish. They use a spear gun or lance-a metal pole with one end a sharpened to a point while the other is bent into a hook that is incredibly useful for catching seacat which hide in holes in the reef. During low tide, at certain moon phases, the inner reef is exposed making it possible to walk from the beach to the Great Rocks in less than waist deep water. There are some holes in the reef that act as pools during these extreme tides and a variety of species can be found in them. During this tidal phase men and women, young and old walk the reef looking for seacat. Younger men swim in the shallows between tides and it is not uncommon for them to come back with 20-30 seacat after 4 or $5 \mathrm{~h}$ of fishing. Because people are fond of seacat, they often share it with one another in a system of asymmetrical reciprocity similar to that in the Bahamas.

When the young men fish the deeper waters they use spear guns and target a variety of reef fish, shellfish, seacat, and other larger pelagic fish. They walk to a point called Mother Frog and swim $1 \mathrm{~km}$ or more out to one of the various reefs in water from 20 to $40 \mathrm{ft}$ deep. The far reefs form the edge of an underwater wall that drops $70 \mathrm{ft}$. This type of fishing lasts for about four $\mathrm{h}$ depending on the weather, water clarity, the strength of the current, and the size of the catch. Currents on the east coast are incredibly strong and have the ability to drag a spear fisherman out to sea or make the swim back to shore extremely arduous. Such fishing continues because reef fish catches are abundant and there are opportunities to catch an occasional large pelagic fish.

The catch is cleaned on the beach in a common use area shaded by large palms, where locals gather for their daily sea baths and acquire some of the fishermen's catch through friendship, kinship, or purchase. Although most fish are used for home consumption, it is seen as an honor to share your catch or to offer a portion of it as a gift. It is one way people measure your worth as an individual and as a fisherman and a way to build social relations.

Fishing in the littoral is important for elders because it is the last portion of the environment that is accessible to them. It represents continued independence because here they can still catch and distribute marine products among family and friends, and thus maintain positive social standing in the community. Every evening at the top of Bath Hill men congregate in the rum shop where there they can view all of the Bath area waters while exchanging stories and information regarding the day's fishing as well as memorable accounts of fishing and the sea.

Elders' attachments to the sea are illustrated by Fred, an 84 year old man who has fished the Bath waters for over 60 years. He is highly regarded as a fisherman-some claim he is the best fisherman in all of Barbados. Fred is emotionally attached to the littoral. He was born in what is now the parking lot of the Bath Beach, in the Government Park. He ties up his boat near Bath Beach. When he fishes for frey, sprats and sardines he does so up and down Bath Beach. Fred lives with his wife at least 15 min away by car near Martins Bay, but he neither ties up his boat nor fishes there. $\mathrm{He}$ is a fisherman from Bath where he knows the reefs, the holes, and inshore areas where he can cast his net for small fish.

The Bath littoral is where young boys come with an older male (usually father or grandfather) to learn to fish. It is difficult to trace how far back this practice goes, but today it is possible to observe at least three generations of men and boys engaged in fishing here. The area outside the Great Rocks has dangerous wave activity and currents, but nearer to shore young boys learn to spearfish for parrot fish (chubs), grunts, silkies and learn how to harvest a variety of shell fish and seacat without much danger. As their skill level and strength increases they swim further offshore to the deep reefs. On the beach, young boys are taught to hand line for sprats, grunts and larger fish. At the bottom of Bath Hill, directly in front of the beach houses, is an area called conch shoal, where, as in the past, people collect conch. It is common to find conch on the way to check the bait on the end of the fixed fishing lines that are tied near shore. Conch shells are returned to shore and not thrown back into the sea grass beds. 
Younger to middle aged men dive for lobster at night, often in coordination with low tide and certain moon phases. Carrying spearguns, lances and dive bags, fishermen can work at least three extended rock/reef formations. It is possible to walk across the reef and submerge in a pool where there are ledges under which lobster and a type of stone crab are found. When walking and swimming from place to place fishers can find "mossy" groupers, chubs, and queen parrot fish sleeping in the grasses and in protected reef areas.

Even though the prime lobster locations in the littoral are generally full of lobster, the fishermen leave them alone during the day because they are perceived as too small. Larger lobster, however, come in from deeper waters during the evening and night, according to some fishermen because the smaller ones are there. The fisherman say that the seacat and the lobster are enemies. Lobsters hide deep within reef and a dead seacat placed inside a reef hole sends the lobster scurrying out. The danger with this strategy is that the seacat is a favorite food of the large green eel-a very aggressive species.

The white sea urchin, locally known as sea eggs, is an important species in the littoral. Like Diadema Antillarum, these urchins are important for balancing algae (Lessios, 1988). White sea urchins are caught seasonally and are a source of food that is culturally important as an indicator of the condition of the sea. Bountiful presence of sea eggs means there is food for all in waist deep water. The centrality of sea eggs in the lives of Barbadians is apparent in the conservation focus of both government regulations and local customs (Mahon and Parker, 1999; cf. Berkes, 1999: 137-139 for St. Lucia). A fishing season was initially established by the government in 1879 and more regulations followed. Local people are known to have community-based rules governing their use of and interactions with sea eggs. Not only are there customary restrictions on use of patches of sea eggs, but knowledgeable fishers are expected to move the sea eggs from one place to another in order to stimulate the formation of new patches. Sea eggs shells, like those of conch, are always broken on the beach and the husks are buried there and never returned to the sea. The ecological implications of this practice, like that of conch shell removal in the Bahamas, have not been tested scientifically, but it is locally considered to be a proper and traditional management technique. In a recent study, breaking sea eggs and discarding the shells on the fishing grounds was seen by local fishers as the major cause of sea egg decline (Mahon et al., 2003: 14).

Local people take sea baths in the littoral zone for health reasons because it is believed that seawater has medicinal value. A young local woman, for example, who bathes her infant daughter in seawater, which she said is good for defeating colds, fever, and the flu, a natural way to help the body heal itself, and as a preventative cleansing method for the skin.

Plants associated with the littoral are important for good health. More than 100 plant species have been recorded growing in the Barbados littoral (Randall, 1970: 163). Some are used to make a medicinal drink called "bush tea," which people will prepare and leave a bottle in public places, such as the rum shop, for other people to use if they are sick. Plants for bush tea are most often collected by local elders because they know the necessary plants and how to prepare the tea.

Cultural connections to the littoral are demonstrated by local actions to protect the area from what locals perceive as ecologically unsound tourism development on the former Bath plantation. A private corporation approached the government about establishing a large-scale tourism facility that would remove most of the natural vegetation, modify the local hydrology, and potentially create polluted runoff into the sea. Although the former Bath plantation is officially owned by the national government, and thus the lands are technically "government land," there is little question that the people of Bath consider these as their communal or family lands. These lands contain the fruits of their labor since slavery. Various trees, such as mango, breadfruit, Bajan apple and coconut trees, have been planted by local people over generations on these steep hills to reduce erosion. They continue to help maintain the fresh water spring which feeds the stream that runs past the village from the top of the hill to the sea. Arguments against the tourism facility are efforts to preserve the natural environment and a portion of communal land, even though the prospects of employment in the facility are attractive to local people.

If development projects or park regulations restrict access to the littoral or permit a tourism facility that pollutes the sea, the people of Bath would become disconnected from this ecosystem. Such changes could eliminate an important place for the cultural transmission of knowledge about natural ways to heal the body and sustain life and a place for elders to maintain their social position and respect.

\section{The Carribbean Littoral and Planned Change}

This analysis focused on the littoral in Barbados and the Bahamas and how these ecological zones have become culturally central over a period of hundreds of years in the lives of two traditional communities. Emancipated Africanancestry slaves, and in Barbados also freed Scots-Irish people, had few resources available to them during and after slavery or imprisonment, but the littoral could be 
sustainably used because it could not be commoditized and thus radically altered by plantation agriculture. Combining land and sea knowledge they increasingly distanced themselves from the colonial powers who first enslaved and then abandoned them. The littoral became the center of their new way of life and it remained so over generations, despite the addition of wage labor which drew them back into the colonial economy. Unlike boom-bust wage labor cycles and the collapsing colonial nation-state around them, they could always count on being sustained by the littoral. They responded by developing complex conservation techniques, based on traditionally acquired knowledge that assured the continuity of the littoral. In post-colonial times, since the late 1960s and early 1970s, these people have fought for control of their community lands, which they own by usufruct rather than by colonial property law. Today, Caribbean lawyers are uniting to understand the prospects of decolonizing the legal systems of these former slave colonies. A central issue is recognition of usufructbased traditional legal systems.

The littoral and its co-adapted traditional people are often underrepresented in social impact assessments of both development and conservation proposals in the Caribbean. Understanding the subtle human-nature connections that have developed here (McDonnel and Pickett, 1993) will result in better informed siting decisions (Boholm and Löfstedt, 2004) and more culturally and environmentally appropriate projects. Especially critical is to assure that the voices of elders and children are heard in the planning process. This study suggests that interdisciplinary research teams composed of ecologists and social scientists are needed to document and more fully understand the marine policy implications at the national, community, and ecosystem levels.

At the human community level, the development of traditional peoples' co-adaptation with their marine environment needs to be systematically studied (Mascia, 2003; Mascia et al., 2003). Such data are distinctive and should not by muted by being averaged with data about newcomers to the coast and non-resident resource users. Data presented in these two cases argued that there is a special role in marine management for traditional people who have lived for generations at the edge of the sea, become coadapted with its natural resources, centered it in their cultural perception of self, and sought to preserve it through conservation behaviors. Changes in their access to the littoral or in the condition of the littoral will impact individual identity, community stability, social organization, food security, and the intergenerational transmission of environmental knowledge. Traditional people have been an important dimension of the littoral so removing them constitutes a trophic shift that must be understood ecologically and socially. The traditional peoples of the Caribbean littoral constitute a specially impacted type of people when coastal projects occur. They are uniquely changed by such projects, but stand to serve in special ways as providers of traditional ecological knowledge, definers of environmental ethics, and as co-managers of these marine resources.

Acknowledgements The Bahamas interdisciplinary study was funded by an NSF biocomplexity grant entitled "Coupled Natural and Human Dynamics in Coral Reef Ecosystems" which was awarded September 2001 as number OCE 0119978. The overall research team was headed by Dr. Daniel Brumbaugh of the American Museum of Natural History. The College of the Bahamas team was headed by Jessica Minnis, Chairperson, School of Social Science, at The College of the Bahamas. Her students included Kendra Arnett, Chervain Dean, Tarah McDonald, Ward Minnis, Tavarrie Smith, and Yasmin Skinner. The University of Arizona team was headed by Richard Stoffle who was joined during the last two field session by Chuck Bollong. Their students included Graduate Assistant Alex Carroll and Clinton Carroll, Fletcher Chmara-Huff, Jill Dumbauld, Richard Gilmour, Arin Haverland, Cory Jones, Shawn Kelley, Noreen Lyell, Aja Martinez, Nathaniel O’Meara, Kathryn Payne, Terra Pierce, Peter Poer, Daniel Post, and Kathleen Van Vlack.

The Barbados study, conducted by Brent Stoffle, was funded by an AT\&T Community Development Grant, the Latin American and Caribbean Initiative at the University of South Florida and the WennerGren Foundation. The study was supervised by professors Trevor Purcell, Susan Greenbaum, Kevin Yelvington, Cheryl Rodriguez, and Michael Conniff.

\section{References}

Anderson, K. (2005). Tending the Wild: Native American Knowledge and the Management of California's Natural Resources. University of California Press, Berkeley, CA.

Atran, S., Medin, D., Ross, N., Lynch, E.,Vapnarsky, V., Ucan Ek,' E., Coley, J., Timura, C., and Baran, M. (2002). Folkecology, Cultural Epidemiology, and the Spirit of the Commons: A Garden Experiment in the Maya Lowlands, 1991-2001. Current Anthropology 43(3): 421-450.

Bain, T. (1995). The Flag of Little Farmers Cay. Brochure.

Barrow, C. (1992). Family Land and Development in St. Lucia. Institute of Social and Economic Research (Eastern Caribbean), Monograph Series no. 1. University of the West Indies, Cave Hill, Barbados.

Bennett, J. (1951). The Problem of Slave Labor Supply at the Codrington Plantations. Journal of Negro History 36(4): 406441.

Berkes, F. (1999). Sacred Ecology: Traditional Ecological Knowledge and Resource Management. Taylor \& Francis, Philadelphia, PA.

Besson, J. (1987). A paradox in Caribbean attitudes to land. In Besson, J. and Momsen, J. (eds.), Land and Development in the Caribbean. MacMillan, London, pp. 13-45.

Besson, J., and Momsen, J. (1987). Land and Development in the Caribbean. Centre for Caribbean Studies, University of Warwick. MacMillan, London.

Boholm, A., and Löfstedt, R. (2004). Facility Siting: Risk, Power and Identity in Land Use Planning. Earthscan, London.

Browne, K. (2004). Creole Economics: Caribbean Cunning under the French Flag. University of Texas Press, Austin, TX.

Christie, P., McCay, B., Miller, M., Lowe, C., White, A., Stoffle, R., Fluharty, D., McManus, L., Chuenpagdee, R., Pomeroy, C., 
Suman, D., Blount, B., Huppert, D., Eisma, R., Oracion, E., Lowry, K., and Pollnac, R. (2003). Towards Developing a Complete Understanding: A Social Science Research Agenda for Marine Protected Areas. Fisheries 28(12): 22-26.

Connell, J. H. (1978). Diversity in Tropical Rain Forests and Coral Reefs. Science 199(4335): 302-1310.

Craton, M. (1987). White Law and Black Custom-The Evolution of Bahamian Land Tenures. In Besson, J. and Momsen, J. (eds.), Land and Development in the Caribbean. Macmillan, London, pp. 88-115.

Craton, M. and Saunders, G. (1992). Islanders in the Stream: A History of the Bahamian People. University of Georgia Press, Athens, GA.

Davidson-Hunt, I. J., and Berkes, F. (2003). Nature and society through the lens of resilience: toward a human-in-ecosystem perspective. In Berkes, F., Colding, J., and Folke, C. (eds.), Navigating Social-Ecological Systems. Cambridge University Press, New York, pp. 53-82.

Duffy, J. E. (2003). Biodiversity Loss, Trophic Skew and Ecosystem Functioning. Ecology Letters 6: 680-687.

Ellison, A., and Farnsworth, E. (1996). Anthropogenic Disturbance of Caribbean Mangrove Ecosystems: Past Impacts, Present Trends, and Future Predictions. Biotropica 28(4): 549-565.

Farnsworth, P. (2001). Negroe houses build of stone besides others watl'd + plaistered: the creation of a Bahamian tradition. In Farnsworth, P. (ed.), Island Lives: Historical Archaeology of the Caribbean. University of Alabama Press, Tuscaloosa, AL, pp. 234-271.

Folke, C., Berkes, F., and Colding, J. (1998). Ecological practices and aocial mechanisms for building resilience and sustainability. In Berkes, F., and Folke, C. (eds.), Linking Social and Ecological Systems. Cambridge University Press, New York, pp. 414-436.

Frank, H. A. (1920). Roaming Through the West Indies. Blue Ribbon Books, New York.

Gmelch, G., and Gmelch, S. (1997). The Parish Behind God's Back: The Changing Culture of Rural Barbados. Waveland Press, Long Grove, IL.

Lamont, B., He, T., Enright, N., Krausss, S., and Miller, B. (2003). Anthropogenic Disturbance Promotes Hybridization Between Banksia Species by Altering Their Biology. Journal of Evolutionary Biology 16: 551-557.

Lessios, H. A. (1988). Mass Mortality of Diadema Antillarum in the Caribbean: What Have We Learned? Annual Review of Ecology and Systematics 19: 371-393.

Lewis, H., and Ferguson, T. (1999). Yards, corridors, and mosaics: how to burn a boreal forest. In Boyd, R. (ed.), Indians, Fire, and the Land in the Pacific Northwest. Oregon State University Press, Corvallis, OR, pp. 64-85.

Loftfield, T. (2001). Creolization in seventeenth-century Barbados. In Farnsworth, P. (ed.), Island Lives: Historical Archaeologies of the Caribbean. The University of Alabama Press, Tuscaloosa, AL, pp. 207-233.

Lutz, S., Broad, K., McManus, L., Sanchirico, J., and Stoffle, R. (2002). Human Dimensions of Marine Reserve Policy. Bahamas Journal of Science 5(2): 50-57.

Mascia, M. (2000). Institutional emergence, evolution, and performance in complex common pool resource systems: Marine protected areas in the Wider Caribbean. PhD Dissertation, Duke University, NC.

Mascia, M. (2003). The Human Dimensions of Coral Reef Marine Protected Areas. Conservation Biology 17(2): 630-632.

Mascia, M., Brosius, P., Dobson, T., Forbes, B., Horowitz, L., McKean, M., and Turner, N. (2003). Editorial-Conservation and the Social Sciences. Conservation Biology 17(3): 649-650.

Mahon, R., and Parker, C. (1999). Barbados Sea Eggs Past, Present, Future. Fisheries Ministry of Agriculture and Rural Development, Barbados.
Mahon, R., McConney, A., Parker, C., and Brewster, L. (2003). Participatory Methodology Used for Sea Urchin Co-Management in Barbados. Ocean \& Coastal Management 46: 1-25.

McCay, B. (2000). Presidential Address Part II: Edges, Fields, and Regions. The Common Property Resource Digest. no. 54: 6-8.

McDonnel, M., and Pickett, S. (eds.) (1993). Humans As Components of Ecosystems: The Ecology of Subtle Human Effects and Populated Areas. Springer, Berlin Heidelberg New York.

Menge, B., Berlow, E., Blanchette, C., Navarrete, S., and Yamada, S. (1994). The Keystone Species Concept: Variations in Interaction Strength in a Rocky Intertidal Habitat. Ecological Monographs 64(3): 249-286.

Milanich, J. (1994). Archaeology of Precolumbian Florida. University Presses of Florida, Tallahassee, FL.

Mokyevsky, O. (1960). Geographical Zonation of Marine Types. Limnology and Oceanography 5(4): 389-396.

Nabham, G. (1995). Cultural parallax in viewing North American habitats. In Soule, M., and Lease, G. (eds.), Reinventing Nature. Island Press, Washington, DC, pp. 87-101.

NRC (National Research Council) (2001). Marine Protected Areas: Tools for Sustaining Ocean Ecosystems. Ocean Studies Board, National Research Council, and National Academy Press, Washington, DC.

Pimm, S. (1991). The Balance of Nature? Ecological Issues in the Conservation of Species and Communities. University of Chicago Press, Chicago.

Randall, R. (1970). Vegetation and Environment on the Barbados Coast. Journal of Ecology 58(1): 155-172.

Robert, N. (1989). The Holocene: An Environmental History. Blackwell, Malden, MA.

Roberts, C. (1995). Effects of Fishing on the Ecosystem Structure of Coral Reefs. Conservation Biology 9(5): 099-995.

Rogers, C., and Beets, J. (2001). Degradation of Marine Ecosystems and Decline of Fishery Resources in Marine Protected Areas in the US Virgin Islands. Environmental Conservation 28(4): 312-322.

Rubino, M., and Stoffle, R. (1990). Who Will Control the Blue Revolution? Economic and Social Feasibility of Caribbean Mithrax Crab Mariculture. Human Organization 49(4): 386-394.

Sheppard, J. (1977). The Red Legs of Barbados: Their Origins and History. KTO, Millwood, NY.

Sheridan, R. (1976). The Crisis of Slave Subsistence in the British West Indies During and After the American Revolution. William and Mary Quarterly 33(4): 615-641.

Sillitoe, P. (2001). Hunting for Conservation in the Papua New Guinea Highlands. Ethnos 66(3): 365-393.

Stoffle, R. (1986). Caribbean Fisherman Farmers: A Social Impact Assessment of Smithsonian King Crab Mariculture. University of Michigan, Institute for Social Research, Ann Arbor, MI.

Stoffle, B. (2001a). 'We don't put all our eggs in one basket': An examination of Meeting Turn, a rotating savings and credit association in Barbados. PhD dissertation, Department of Anthropology, University of South Florida, Tampa, FL.

Stoffle, R. (2001b). When fish is water: food security and fish in a coastal community in the Dominican Republic. In McGoodwin, J. (ed.), Understanding the Cultures of Fishing Communities: A Key to Fisheries Management and Food Security. Food and Agricultural Organization of the United Nations; FAO Fisheries Technical Paper 401, Rome, Italy, pp. 219-245.

Stoffle, R., Halmo, D., Stoffle, B., Williams, A., and Burpee, G. (1993). An ecosystem approach to the study of coastal areas: a case from the Dominican Republic. In Ness, G., Drake, W., and Brechin, S. (eds.), Population-Environmental Dynamics. University of Michigan Press, Ann Arbor, pp. 253-282.

Stoffle, B., Halmo, D., Stoffle, R., and Burpee, G. (1994a). Folk management and conservation ethics among small-scale fishermen of Buren Hombre, Dominican Republic. In Dyer, C., and 
McGoodwin, J. (eds.), Folk Management in the World's Fisheries. University of Colorado Press, Boulder, Colorado, pp. $115-138$.

Stoffle, R., Halmo, D.,Wagner, T., and Luczkovich, T. (1994b). Reefs From Space: Satellite Imagery, Marine Ecology, and Ethnography in the Dominican Republic. Human Ecology 22 (3): $355-378$

Stoner, A. (1997). Shell Middens as Indicators of Long-term Distributional Pattern in Strombus gigas, a Heavily Exploited Marine Gastropod. Bulletin of Marine Science 61(3): 570-599.

Sturge, J., and Harvey, T. (1968). The West Indies in 1837: Being the Journal of a Visit to Antiqua, Monserrat, Dominica, St. Lucia, Barbados, and Jamaica. Frank Cass \& Co. Ltd, London.

Trollope, A. (1860, 1980). The West Indies and the Spanish Main. Harper \& Brothers, New York.

Turner, N., Davidson-Hunt, I., and O'Flaherty, M. (2003). Living on the Edge: Ecological and Cultural Edges as Sources of Diversity for Social-Ecological Resilience. Human Ecology 31(3): 439461.

Watts, D. (1994). The West Indies: Patterns of Development, Culture, and Environmental Change since 1492. Cambridge University Press, London.

Williams, E. (1944). Capitalism \& Slavery. University of North Carolina Press, Chapel Hill, NC.

Wing, E., and Scudder, S. (1983). Animal exploitation by prehistoric people living on a tropical marine edge. In Grigson, C., and Clutton-Brock, J. (eds.), Animals and Archaeology, Vol. 2: Shell Middens, Fishes, and Bird. BAR International Series no. 183, Oxford, UK, pp. 197-210.

Wood, P. H. (1974). Black Majority: Negroes in Colonial South Carolina. W. W. Norton \& Company, New York.

Yates, A. (1998). Red leg fishermen at Martins Bay Circa 1910. In Yates, A. (ed.), Bygone Barbados. Black Bird Studios, St. Michael, Barbados, pp. 151. 